Bond University

Research Repository

\title{
Challenging Conceptions of Accessory Liability in Private Law
}

Ridge, Pauline; Dietrich, Joachim

Published in:

Cambridge Law Journal

DOI:

10.1017/S0008197319000345

Licence:

CC BY-NC-ND

Link to output in Bond University research repository.

Recommended citation(APA):

Ridge, P., \& Dietrich, J. (2019). Challenging Conceptions of Accessory Liability in Private Law. Cambridge Law Journal, 78(2), 383-408. https://doi.org/10.1017/S0008197319000345

\footnotetext{
General rights

Copyright and moral rights for the publications made accessible in the public portal are retained by the authors and/or other copyright owners and it is a condition of accessing publications that users recognise and abide by the legal requirements associated with these rights.
}

For more information, or if you believe that this document breaches copyright, please contact the Bond University research repository coordinator. 


\title{
CHALLENGING CONCEPTIONS OF ACCESSORY LIABILITY IN PRIVATE LAW
}

\author{
PAULINE RIDGE* AND JOACHIM DIETRICH**
}

This article concerns recent challenges to the utility of 'accessory liability' as an organising principle or concept in private law and argues that accessory liability is a coherent body of law with common features that is worthy of separate, holistic treatment. We defend a conceptual framework for accessory liability which is dynamic in its operation and which does not dictate the precise legal content of accessory liability in different contexts. Such a conception of accessory liability has come under challenge from recent cases and commentary which either minimise the scope and analytical relevance of accessory liability altogether in equity and tort law or propound a conceptual framework for accessory liability that is fixed in its application and uniform in its content across the whole of private law. Our purpose in this article is to resist both the dismissal of, and simplification of, accessory liability in private law.

\section{INTRODUCTION}

It is rare for the law to impose liability on one person for wrongful conduct engaged in by another. Accessory liability is one instance in which this occurs. In broad terms, accessory liability arises where a party involves herself in another's wrongdoing - the primary wrong - with a sufficient mental state such as to be legally at fault. That fault justifies the accessory (A) being held liable to the claimant (C) to remedy the consequences of the primary wrong.

In previous work we argued that accessory liability in private law is a coherent body of law with common features that is worthy of separate, holistic treatment. ${ }^{1}$ We proposed a conceptual framework that is dynamic in its operation and that does not dictate the precise legal content of accessory liability in different contexts. This conception of accessory liability does not depend upon whether the accessory is liable for the same wrong as the primary wrongdoer (that is, they are joint wrongdoers) or is held liable for a different wrong (that is, accessory liability constituting a distinct wrong). Hence, it reaches into most areas of private law.

Since then, however, several very different views about the role of accessorial concepts in the law have either emerged or crystallised. On the one hand, some commentators minimise the scope and analytical relevance of accessory liability to equity and tort law. These views are evident in recent scholarly treatments and are given some support in a recent Australian case at the highest level. Such approaches challenge the utility of analysing or indeed, describing, liability as accessorial. On the other hand, a recent monograph accepts the importance of

\footnotetext{
* Australian National University.

** Bond University. We are grateful to the anonymous reviewers for their generous and constructive reviews.

${ }^{1}$ See generally J. Dietrich and P. Ridge, Accessories in Private Law (Cambridge 2015).
} 
accessory liability, but propounds a conceptual framework for the liability that is fixed in its application and uniform in its content. Our purpose in this article is to resist both the dismissal, and simplification, of accessory liability in private law that is evident in these recent developments. Hence, the article concerns the utility of 'accessory liability' as an organising principle or concept in private law. Does accessory liability, as we will explain it, still make better sense of certain liabilities across private law than other explanations of those liabilities, including other conceptions of accessory liability itself?

The topic is important. Legal theorising of the type discussed in this article is not completely abstracted from the law in practice. The shared objective of each of the conceptions of law critiqued below is to explain the law from an internal legal perspective in a way that will assist courts and legislators to develop that law in a coherent fashion. Whichever conception, if any, finds favour with the courts will have practical ramifications for the conduct, and outcome, of litigation. This is because the requisite elements of liability, the judicial method for determining whether such elements are satisfied, as well as the boundaries of liability in different areas of law, are all affected by one's conception of the liability itself.

After briefly outlining our preferred conception of accessory liability (Part II) and the terminological confusion regarding accessory and related liabilities (Part III), the article continues in Part III to discuss two conceptual challenges to accessory liability that would dramatically reduce its scope and relevance in equity and in the law of torts respectively. These approaches dismiss the relevance of accessory liability altogether. Part IV evaluates an alternative conception of accessory liability itself and argues that it promotes a degree of uniformity and simplicity that is at odds with, and to the detriment of, the existing law.

The jurisdictional focus is on English and Australian private law: although the laws in these two jurisdictions have a common heritage, they have also diverged in significant ways, particularly in the context of equitable accessory principles, such as to provide a useful comparison. $^{2}$

\section{THE PREFERRED CONCEPTION OF ACCESSORY LIABILITY}

\footnotetext{
${ }^{2}$ Although it will be necessary in Part III C to consider briefly the criminal law of complicity, the fundamental differences between civil and criminal law, as well as the complexity and confusion surrounding criminal accessory and related liabilities, make anything other than peripheral consideration of the criminal law unwise and unhelpful.
} 
Across private law, one circumstance in which liability will be imposed on a person for the wrongful conduct of another is where three elements are present:

(i) A primary wrong ${ }^{3}$ committed by a person (the primary wrongdoer, $\mathrm{PW}$ );

(ii) Involvement, through conduct, by someone other than PW (the accessory, A), in the primary wrong; and,

(iii) A has a requisite mental state relating to the primary wrong at the time of the conduct.

At its simplest, it can be said that accessory liability arises where a party involves herself in another's wrongdoing with a sufficient mental state such as to be legally at fault and, thus, responsible. It is necessary, however, to add three details to this bare conceptual framework in order to accurately represent the scope and operation of accessory liability across private law. They concern the legal content of each element, the dynamic operation of the framework and the form of liability.

First, the doctrinal or legislative content of the conduct (ii) and mental (iii) elements of the framework - and hence, fault - is determined by reference to the purposes and values of the law governing the primary wrong, element (i). Importantly, this means that the precise content of elements (ii) and (iii) may and does vary. Accordingly, the framework does not dictate that the legal rules for accessory liability be identical across private law. In other words, the framework does not constitute a generic cause of action, but rather an organising principle of liability. For example, the equitable wrong of dishonest (or knowing) assistance has less onerous conduct and knowledge requirements than the tort of inducing breach of contract. Nonetheless, both embody the same conceptual framework for liability. ${ }^{4}$

Secondly, the three elements of the framework relate in dynamic fashion. In particular, there is a relationship between the weightings accorded to elements (ii) and (iii) which in combination establish liability. In some areas of law and jurisdictions the dynamic operation of the framework manifests at the level of the judicial inquiry into liability. An example is the requirement for equitable accessory liability in English law that A be 'dishonestly' involved in

\footnotetext{
${ }^{3}$ We use the term 'wrong' in a broad, but conventional sense, to mean breach of a legal duty that leads to remedial outcomes and as including breaches of common law and equitable duties. Breaches of statutory duty that give rise to private action also come within the ambit of 'wrong'.

${ }^{4}$ Cf., Royal Brunei Airlines Sdn Bhd v Tan [1995] 2 A.C. 378, 392 and OBG Ltd v Allan [2007] UKHL 21, [2008] 1 A.C. 1 , at [39]-[44].
} 
any breach of trust or fiduciary duty. ${ }^{5}$ This requires a normative judgement to be made as to A's conduct in all the circumstances, including A's mental state. ${ }^{6}$ In other jurisdictions this dynamic feature is embedded in the doctrinal formulation. For example, the equivalent Australian equitable doctrine of knowing assistance requires that A knowingly involve herself in 'a dishonest and fraudulent design' by the trustee or fiduciary. ${ }^{7}$ Here, an egregious primary wrong is required; consequently, the conduct and mental elements are set at a relatively low level (assistance and 'knowledge of circumstances which would indicate the facts to an honest and reasonable man'). ${ }^{8}$ Whereas, in the same jurisdiction, A will be liable for procuring, rather than assisting, any breach of trust; that is, the stronger conduct and mental elements connoted by procurement allow for a less egregious primary wrong. ${ }^{9}$

Thirdly, the substantive nature of A's liability does not depend upon whether the law characterises it as liability for a wrong that is separate and distinct from the wrong for which PW is liable. This is of significance to our claim: A's liability is accessorial provided it is both necessary and sufficient to prove that A culpably involved herself in PW's wrongdoing. An example of a liability being accessorial in substance but expressed as a different wrong is the tort of inducing breach of contract. The liability is a tort for historical and conceptual reasons including that only a party to the contract could be liable in contract law. ${ }^{10}$ But the requisite elements for liability are: (i) the commission of a wrong in the form of a breach of contract by PW; (ii) A's involvement in the commission of that wrong through inducement of PW to breach; and (iii) that A has the requisite mental state at the time of involvement. ${ }^{11}$ Thus, the liability is accessorial to another's breach of contract. ${ }^{12}$

Accessory liability for the same wrong as committed by PW arises where parties are liable as joint tortfeasors. Joint tortfeasors are liable for the same tort as that committed by PW, but on a variety of grounds, including vicarious liability of employers and principals. ${ }^{13}$ Some joint tortfeasors are liable on accessorial grounds because it must be shown that they involved themselves in another's tortious conduct with a requisite mental state. For example, if A

\footnotetext{
${ }^{5}$ See Royal Brunei Airlines Sdn Bhd v Tan [1995] 2 A.C. 378, 387; Twinsectra Ltd v Yardley [2002] UKHL 12, [2002] 2 A.C. 164; Abou-Rahmah v Abacha [2006] EWCA (Civ) 1492, [2007] Bus.L.R. 220. See further Part IV B 3.

${ }^{6}$ Ibid.

${ }^{7}$ See Farah Constructions Pty Ltd v Say-Dee Pty Ltd (2007) 230 C.L.R. 89.

${ }^{8}$ Ibid.

${ }^{9}$ Ibid.

${ }^{10}$ See further, Dietrich and Ridge, Accessories, at para. [6.2.1].

${ }^{11}$ Ibid., at ch. 6.

${ }^{12}$ OBG Ltd v Allan [2007] UKHL 21, [2008] 1 A.C. 1.

${ }^{13}$ See Baxter v Obacelo Pty Ltd [2001] HCA 66, (2001) 205 C.L.R. 635 at [24].
} 
procured PW, or entered a common design with PW, to commit a tort (such as trespass), but did not herself carry out the acts constituting its elements (A did not enter C's land, for example), A's liability is accessorial even though in form A's liability is for the same tort (the trespass) as PW. ${ }^{14}$

The distinction in tort law between liability that is not accessorial, and liability that is, is not always easy to draw in practice. For example, where two parties carry out the same act together, or carry out parts of a combination of acts that together form the conduct elements of a wrong or multiple wrongs, the facts could be analysed either as raising primary liability only, or accessory liability where the parties are primary wrongdoers and accessories both at the same time. ${ }^{15}$ Such scenarios pose an unavoidable challenge in distinguishing accessory liability from other types of liability and are discussed further at Part III C (5).

Thus, three features distinguish our preferred conception of accessory liability: the legal content of the conduct and mental elements is not fixed and depends upon the purposes and values of the law of the primary wrong; there is a proportionality between the primary wrong and the conduct and mental elements; and A's liability can be for a separate wrong or for the same wrong for which PW is liable. ${ }^{16}$

\section{NON-ACCESSORIAL CONCEPTIONS OF LIABILITY}

This Part considers two non-accessorial conceptions of parts of private law that challenge the explanatory power and breadth of our preferred conception of accessory liability and that have recently come to the fore. They concern equitable accessory liability and the accessory liability of joint tortfeasors respectively. First, however, it is necessary to address the terminological complexity and confusion that abounds.

\section{A. Terminology}

\footnotetext{
${ }^{14}$ See, e.g., Hume v Oldacre (1816) 1 Starke 351, 171 E.R. 494; Schumann v Abbot [1961] S.A.S.R. 149.

${ }^{15}$ A different problem of distinguishing primary from accessory liability arises in categorising some causes of action. For example, the tort of conspiracy largely overlaps with accessory liability, but has a remnant, distinct sphere of operation that does not. This means that conspiracy cannot be categorised as a form of accessorial liability, though most examples of conspiracy would also, factually, be able to substantiate a claim of joint tortfeasance as accessories. See Dietrich and Ridge, Accessories, at para. [5.3.2]. For a more radical reordering of the law, see P. Davies and P. Sales, 'Intentional Harms, Accessories and Conspiracies' (2018) 134 L.Q.R. 69.

${ }^{16}$ It should also be noted that the fact that a person's liability is dependent upon another party committing a wrong does not mean that the liability is always accessorial. Vicarious liability is an obvious example. Another example is that a defendant may be independently liable for negligently failing to prevent a tortfeasor's tortious conduct that harms C. See, e.g., Smith v Leurs (1945) 70 C.L.R. 256, 262. In neither example will the defendants have knowingly involved themselves in the third party's wrongdoing.
} 
One significant challenge to developing a comprehensible conception of accessory liability is terminological. A variety of terms are used to describe accessory liability or the various tests for or elements of it in different areas of private law; many have overlapping, similar or identical meanings. ${ }^{17}$ There is no authorised dictionary for accessory liability and its counterparts, yet often courts and commentators assume that there is. Terms such as primary, secondary, ancillary, derivative and, indeed, accessory or accessorial, are assumed to have selfevident meanings when they do not. Worse still, the assumed meanings may be diametrically opposed. Courts are also understandably wary of importing novel terminology into established areas of law, particularly when such terminology is viewed as the product of academic scholarship. Such reluctance is exacerbated in equity, perhaps because of the criminal and common law provenances of accessorial terminology.

Examples of how these terminological challenges affect the cogency of judicial reasoning can be found in a recent Australian case concerning knowing participation in dishonest and fraudulent breaches of fiduciary duty and the remedy of account of profits. In Lifeplan Australia Friendly Society Ltd v Ancient Order of Foresters in Victoria Friendly Society Ltd, ${ }^{18}$ the Full Federal Court of Australia was required to determine the requisite causal link for an account of profits to be awarded against the knowing participant. The English Court of Appeal had considered the same question in relation to the analogous English claim for dishonest assistance in breach of trust or fiduciary duty (described by the English court as an 'accessory liability'). ${ }^{19}$ One reason given by the Full Court for finding the reasoning of the English court was not relevant was that, in its view, the Australian liability 'is not strictly accessorial. It is a liability, in Equity, imposed directly on the third party'. ${ }^{20}$ With respect, this reasoning is flawed because it is contrary to High Court of Australia authority that has characterised knowing assistance as an independent wrong (that is, 'imposed directly' upon A), but nonetheless as an accessory liability. ${ }^{21}$

\footnotetext{
${ }^{17}$ The over-proliferation of terms is a product of the independent development of accessory liability in different areas of law.

${ }^{18}$ (2017) 250 F.C.R. 1. An appeal to the High Court of Australia was heard on 12 April 2018 and the appeal was allowed as to the quantification of the profit: see Ancient Order of Foresters in Victoria Friendly Society Ltd $v$ Lifeplan Australia Friendly Society Ltd [2018] HCA 43.

${ }^{19}$ Novoship (UK) Ltd v Mikhaylyuk [2014] EWCA (Civ) 908, [2015] Q.B. 499.

${ }^{20}$ Lifeplan Australia Friendly Society Ltd v Ancient Order of Foresters in Victoria Friendly Society Ltd (2017) 250 FCR 1, at [68].

${ }^{21}$ Michael Wilson \& Partners Ltd v Nicholls (2011) 244 C.L.R. 427, 457 at [106].
} 
Only Justice Gageler engaged with terminological issues on the appeal of the Full Court's decision to the High Court. ${ }^{22}$ His Honour accepted that 'accessorial' was a useful description of the equitable liability, but preferred to describe the liability as 'ancillary'. ${ }^{23}$ A distinction was drawn between the two descriptors: 'accessorial' was said to emphasise that it is the nature of the primary wrong that makes A's conduct unconscionable, whereas 'ancillary' emphasised that it is A's knowing participation that attracts liability 'to account "as if" a fiduciary'. ${ }^{24}$ But with respect, the meaning of this passage is obscure and the terminology does nothing to enhance its clarity. Surely, 'accessorial' and 'ancillary' are interchangeable terms in this (or any other) context? Perhaps 'ancillary' is the more neutral descriptor of the two as it has no criminal or common law connotations, but that is not the reason given by Gageler J. Thus, to say that the liability is 'ancillary', rather than 'accessorial' tells us very little; those terms do not have a settled legal meaning and are used interchangeably in non-legal contexts.

In the following discussion we note where terminological ambiguity arises. The point of doing so is not to insist that others adopt our preferred terminology; rather, it is to highlight the lack of transparency regarding the labels used for accessory and related liabilities. It is also necessary to identify such ambiguities in order to understand and evaluate the claims being made.

\section{B. An Alternative Conception to Accessory Liability for Breach of Trust or Fiduciary}

\section{Duty: 'A' is a Fiduciary}

Equitable liability for procurement or assistance in another's equitable wrong conforms to the conceptual framework for accessory liability set out in Part II. This is uncontroversial and finds strong support in the current law in both England and Australia. ${ }^{25}$

An alternative conception to that of accessory liability in equity is proposed by Sarah Worthington. ${ }^{26}$ She denies that accessory liability has any role to play here, essentially because

\footnotetext{
${ }^{22}$ Ancient Order of Foresters in Victoria Friendly Society Ltd v Lifeplan Australia Friendly Society Ltd [2018] HCA 43 at [76]-[77].

${ }^{23}$ Ibid., at [77] citing Williams $v$ Central Bank of Nigeria [2014] A.C. 1189 at [9].

${ }^{24} \mathrm{Ibid}$

${ }^{25}$ Twinsectra Ltd $v$ Yardley [2002] UKHL 12, [2002] 2 A.C. 164 (following Royal Brunei Airlines Sdn Bhd v Tan [1995] 2 A.C. 378); Abou-Rahmah v Abacha [2006] EWCA (Civ) 1492, [2007] Bus.L.R. 220 (following Barlow Clowes International Ltd (in liq) v Eurotrust International Ltd [2005] UKPC 37, [2006] 1 W.L.R. 1476). In Australia see Michael Wilson \& Partners Ltd v Nicholls (2011) 244 C.L.R. 427, 457 at [106].

${ }^{26}$ S. Worthington, "Exposing Third-Party Liability in Equity: Lessons from the Limitations Rules" in P.S. Davies and J.E. Penner (eds.), Equity, Trusts and Commerce (Oxford 2017), 331. The catalyst and context for Worthington's arguments is the Limitation Act 1980 (UK) and its interpretation by the UK Supreme Court in Williams v Central Bank of Nigeria [2014] UKSC 10, [2014] A.C. 1189. We do not seek to defend that decision in our evaluation of Worthington's arguments.
} 
it is surplus to requirements. She argues that a dishonest assistant or procurer of a breach of trust or fiduciary duty is themselves a fiduciary (and also a trustee if they held, or continue to hold, trust property). The requirements that we would characterise as accessorial, namely, involvement in the primary wrong with the requisite mental state, are used by Worthington to justify the imposition of fiduciary - and if A holds trust property, trust - obligations on A. The same analysis is applied to knowing recipients and innocent donees of trust property in breach of trust.

To explain why A is a trustee or fiduciary, Worthington unpacks the language of constructive trusts that was traditionally used to describe A's liability. She concludes that constructive trustees are:

simply people owing trustee-like personal obligations in relation to the management of another's property...[T]hey are, in short, fiduciaries, made so by virtue of the personal obligations to which they are subject. ${ }^{27}$

They are subject to these personal obligations because they have assumed the care or management of property known to belong to others. ${ }^{28}$ The extent of the obligations (whether encompassing fiduciary duties) depends upon the extent to which they know of the terms of the original trust or fiduciary relationship. ${ }^{29}$

According to Worthington, if a dishonest assistant is subject to trust and fiduciary obligations, it makes perfect sense that they are subject to the same extensive remedies as other trustees and fiduciaries when they breach those obligations. Moreover, the availability of disgorgement remedies such as an account of profits only makes sense if $\mathrm{A}$ is a fiduciary. If Worthington is correct, then there is virtually no scope for accessory liability in equity: it is a redundant concept.

\footnotetext{
${ }^{27}$ Worthington, 'Exposing Third-Party Liability in Equity', at p. 338.

${ }^{28}$ Ibid., at p. 341.

${ }^{29}$ Ibid., at pp. 339-340.
} 
In the following discussion we identify and evaluate three key elements of Worthington's analysis. Worthington's reasoning focuses upon liability for dishonest assistance, rather than procurement, ${ }^{30}$ and we will do the same. ${ }^{31}$

\section{Worthington's characterisation of the nature of equity}

Worthington's thesis is premised upon a characterisation of equity as being quintessentially about property:

The key insight is to notice that equity's unrelenting focus is on property-holding and property-management. In particular, equity's focus is on the property itself, and not on the parties with interests in the property or with claims in respect of its mismanagement. It is this property focus, rather than a claimant focus, which marks a powerful divide between equity and the common law, with some striking consequences. ${ }^{32}$

The consequence for those involved in a breach of trust or fiduciary duty is that equity:

determines the liability of strangers to an express trust, or strangers to the propertymanagement relationship, very directly: it asks whether these people, too, are trustees or fiduciaries or both. ${ }^{33}$

Equity's focus upon property is crucial to Worthington's reasoning: dishonest assistants are fiduciaries because they are either property holders or property managers for others. They become liable for knowingly breaching the equitable duties associated with property holding and/or management.

This is a difficult claim to evaluate due to its generality. Nonetheless, a question that immediately arises is why Worthington contrasts a 'property focus' with a 'claimant focus', implying that they are the only, mutually exclusive, possibilities? Contrary to Worthington's characterisation of equity as focussed solely on property, courts express the principled rationales for dishonest or knowing assistance liability in relational terms. For example, A's

\footnotetext{
${ }^{30}$ This is due, in our view, to terminological confusion regarding the meaning of 'primary wrong'. See particularly ibid., at p 346 where it is argued that liability for procuring a breach of trust or fiduciary duty cannot be accessory liability 'since the "primary" or instigating wrong is the inducer's, not the trustee's or fiduciary's'. This is a novel use of 'primary' and misunderstands its meaning in the context of 'primary wrong'. The adjective 'primary' in its ordinary use does not describe the chronology of wrongdoing or how the wrong originated, but rather the origin of C's rights against $\mathrm{PW}$ and $\mathrm{A}$.

${ }^{31} \mathrm{We}$ will not evaluate the force or otherwise of her reasoning as it applies to recipient liability or to the liability of innocent donees of misappropriated trust property. The case for assimilating these liabilities with trust and fiduciary law is stronger than that for assistance-based liability because of the requisite trust property element.

${ }^{32}$ Worthington, 'Exposing Third-Party Liability in Equity', at pp. 332-333.

${ }^{33}$ Ibid., at pp. 345.
} 
culpability is described in terms of A knowingly taking advantage for personal gain of the equitable relationship between the claimant beneficiary or principal, $\mathrm{C}$ and $\mathrm{PW},{ }^{34}$ or deliberately interfering in the relationship between $\mathrm{C}$ and PW. ${ }^{35}$ There are also pragmatic rationales for liability: these do indeed include the protection of trust property, ${ }^{36}$ but also the objectives of deterring breaches of trust and fiduciary duty by dissuading others from participating in such breaches, ${ }^{37}$ and the vindication of C's rights by providing $\mathrm{C}$ with an alternative defendant in $\mathrm{A} .{ }^{38}$

Even if we attempt, as Worthington does, to extract abstract propositions from the case law that are not necessarily supported by what judges say they are doing, her characterisation of equity does not resonate with the operation of current English or Australian law. Equity's jurisdiction is founded upon 'conscience', not property per se; and equitable intervention ranges far beyond property-related scenarios. ${ }^{39}$ The undoubted presence of a large and complex body of equity concerning the management of trusts and trust property does not mean that the equitable norms at play are focused solely upon the inviolability of such property.

A further and more obvious problem with a property-focussed analysis is that property-related wrongdoing is not a prerequisite for either breach of fiduciary duty or knowing assistance or procurement liability. That is, misappropriation of trust property - including property under the control of a fiduciary, such as corporate property - is not an essential element for A's liability. Where there is no property involved, Worthington's claim that '[i]n equity, however, the relationship under the microscope is not that between the accessory and the primary wrongdoer; it is the relationship between the accessory and the managed property ${ }^{40}$ does not make sense. Despite obiter comments in the House of Lords and UK Supreme Court that apparently assume that the primary wrong will involve misapplication of trust property, ${ }^{41}$ the English Court of Appeal has directly considered the question, in the (non-property-related)

\footnotetext{
${ }^{34}$ See, eg, Fyffes Group Ltd v Templeman [2000] 2 Lloyd's Rep 643, 669; Novoship (UK) Ltd v Mikhaylyuk [2014] EWCA (Civ) 908, [2015] Q.B. 499 at [76] (citing Consul Development Pty Ltd v DPC Estates Pty Ltd (1975) 132 C.L.R. 373, 397).

${ }^{35}$ Royal Brunei Airlines Sdn Bhd v Tan [1995] 2 A.C. 378, 386-387.

${ }^{36}$ See, e.g., Zhu v Treasurer of New South Wales (2004) 218 C.L.R. 530, at [120]-[121].

${ }^{37}$ Novoship (UK) Ltd v Mikhaylyuk [2014] EWCA (Civ) 908, [2015] Q.B. 499, [76] (citing Consul Development Pty Ltd v DPC Estates Pty Ltd (1975) 132 C.L.R. 373, 397).

${ }^{38}$ Royal Brunei Airlines Sdn Bhd v Tan [1995] 2 A.C. 378, 386-387.

${ }^{39}$ Lord Millett, 'The Common Lawyer and the Equity Practitioner' (2015) 6 UK Supreme Court Yearbook 175, 179.

${ }^{40}$ Worthington, 'Exposing Third-Party Liability in Equity', at p. 345.

${ }^{41}$ See, eg, Twinsectra Ltd v Yardley [2002] UKHL 12, [2002] 2 A.C. 164 at [107] (Lord Millett): 'liability for misdirected funds'; Williams v Central Bank of Nigeria [2014] UKSC 10, [2014] A.C. 1189 at [9] (Lord Sumption JSC, Lord Hughes JSC agreeing): 'participation in the unlawful misapplication of trust assets'.
} 
context of a fiduciary taking bribes to enter certain contracts on behalf of his principal, and found otherwise:

[I]n a case for accessory liability there is no requirement for there to be trust property. Such a requirement wrongly associates accessory liability with trust concepts ... Accessory liability does not involve a trust. It involves providing dishonest assistance to somebody else who is in a fiduciary capacity [and] has committed a breach of his fiduciary duties. ${ }^{42}$

It is also clear in Australia that equitable liability for knowing assistance in a dishonest and fraudulent design can arise whether or not the primary wrong involves a misappropriation of trust property. ${ }^{43}$ Moreover, how does one explain the occurrence of accessory liability for breach of confidence, admittedly narrow as it is, if there must be property involved? ${ }^{44}$ In summary, Worthington's characterisation of equity as being focussed upon property and hence mandating the direct imposition of trust or fiduciary property-related obligations on knowing assistants is unpersuasive.

\section{Conservatism regarding equitable remedies}

Worthington's reasoning reflects her concern regarding the intrusion of equitable remedies into commercial dealings. A repeated theme of her argument is that the dishonest assistant is subject to the same range of remedies as a trustee or fiduciary and the only way that this can be justified is if the dishonest assistant is actually a trustee or fiduciary. The implication is that equitable remedies are disruptive and must be kept in check. In particular, Worthington is troubled by the availability of an account of profits, which, she says, is 'remarkably rare' outside fiduciary law: ${ }^{45}$

So when dishonest assistants are compelled to disgorge the personal gains derived from non-compliance with particular property-management duties, as they are, then

\footnotetext{
${ }^{42}$ Novoship (UK) Ltd v Mikhaylyuk [2014] EWCA (Civ) 908, [2015] Q.B. 499 [91] (Longmore, Moore-Bick and Lewison LJJ) quoting JD Wetherspoon plc v Van de Berg \& Co Ltd [2009] EWHC 639 at [510]-[520] (Peter Smith J). See further Dietrich and Ridge, Accessories, at para. [8.3.1.3].

${ }^{43}$ Consul Development Pty Ltd v DPC Estates Pty Ltd (1975) 132 C.L.R. 373; Farah Constructions Pty Ltd v Say-Dee Pty Ltd (2007) C.L.R. 89.

${ }^{44}$ Cf., Vestergaard Frandsen A/S v Bestnet Europe Ltd [2013] UKSC 31, [2013] 1 W.L.R. 1556. See also, OBG Ltd v Allan [2007] UKHL 21, [2008] A.C. 1 at [276].

${ }^{45}$ Worthington, 'Exposing Third-Party Liability in Equity', at p. 343.
} 
classification of these people as fiduciaries seems irresistible, notwithstanding the courts' explicit denial of that conclusion. ${ }^{46}$

This downplays the fact that an account of profits clearly is available in non-fiduciary contexts, such as intellectual property ${ }^{47}$ and breach of confidence. ${ }^{48}$ Indeed, the remedy is not controversial in those contexts. This does not mean, however, that those forms of liability need to be (re)-characterised as fiduciary. It is also not clear why the availability of the full range of equitable remedies against an accessory is unjustified. Why, for instance, is it unthinkable that a fiduciary's spouse who is complicit in the fiduciary's wrongful diversion of profits from the principal to her should be liable to disgorge those profits on the accessorial basis of dishonest assistance in the fiduciary's breach of duty? The courts clearly do recognise the availability of an account of profits for knowing or dishonest assistance liability ${ }^{49}$ and, as discussed above, the principled rationales for such liability clearly encompass gain-motivated conduct.

\section{Is accessory liability an 'additional loop'?}

A third key element of Worthington's reasoning is that her thesis is direct and simple, ${ }^{50}$ whereas an accessory liability analysis is an 'additional loop'. ${ }^{51}$ But is this so? On Worthington's approach it is first necessary to prove that:

1. A 'assumed the care or management of property';

2. 'known to belong to others'.

At this point, it is established that A was a fiduciary and perhaps also a trustee. It is then necessary to prove that there was:

3. a subsequent breach of trust or fiduciary duty by A. ${ }^{52}$

In order to establish accessory liability, one must also prove three elements, namely:

(i) the primary wrong of breach of fiduciary duty by PW;

\footnotetext{
46 Ibid.

${ }^{47}$ See eg Patents Act 1977 (UK), s. 61; Dart Industries Inc v Decor Corporation Pty Ltd (1993) 179 C.L.R. 101.

${ }^{48}$ Peter Pan Manufacturing Corp v Corsets Silhouette Ltd [1964] 1 W.L.R. 96, 106; OBG Ltd v Allan [2007] UKHL 21, [2008] A.C. 1 at [276].

${ }^{49}$ Novoship (UK) Ltd v Mikhaylyuk [2014] EWCA (Civ) 908, [2015] Q.B. 499: Ancient Order of Foresters in Victoria Friendly Society Ltd v Lifeplan Australia Friendly Society Ltd [2018] HCA 43. See also Michael Wilson \& Partners Ltd v Nicholls (2011) 244 C.L.R. 427, 457 at [106].

${ }^{50}$ See eg Worthington, 'Exposing Third-Party Liability in Equity', at pp. 357-358. See further Part IV below concerning the prioritisation of uniformity and simplicity in the law.

${ }^{51}$ Worthington, 'Exposing Third-Party Liability in Equity', at p. 345.

${ }^{52}$ Ibid., at pp. 339-340.
} 
(ii) A's involvement through conduct in the primary wrong; and

(iii) that $\mathrm{A}$ had the requisite mental state.

Since the subject-matter of elements 1. and 2. of Worthington's framework, concerning A's conduct and knowledge, equates to the subject-matter of elements (ii) and (iii) of our accessorial framework, on either approach three distinct elements must be established for liability to arise: a conduct and mental element, as well as a wrong (whether by the original fiduciary on Worthington's approach or by A on our approach). Worthington's conception of A's liability is no more direct or simpler.

In summary, to conceive of dishonest assistants as fiduciaries in their own right, rather than as accessories, does not reflect either the scope of the liability (which goes beyond propertyrelated scenarios) or the principled rationales for liability (which are relational) or the range of pragmatic rationales (which include, but are not limited to, property-protection). It reflects a distrust of gain-based remedies which, in our view, is ungrounded. Nor does the fiduciary route to liability prove simpler. Finally, as Worthington candidly acknowledges, much of her analysis is contrary to the language and the reasoning of the courts. Surely that must give one pause for thought? Why would the courts have got it so wrong? ${ }^{53}$ And, if Worthington is correct, how can this be remedied?

\section{Attribution of Acts, Attribution of Liability, or Accessory Liability?}

\section{Introduction}

A second challenge to our preferred conception of accessory liability in private law comes from an alternative explanation for certain liabilities in tort law. In brief, it is claimed that the tort liability of one who acts in concert with another (or procures another) to commit a tort, and where only the latter commits the conduct element of the tort, is based upon the attribution of the latter's acts to the former. Because the attribution is of acts, rather than liability, the former's joint tortfeasor liability is said to be a 'primary' liability which is personal to that tortfeasor, as opposed to a 'derivative' liability which depends upon the actual actor (whom we would call the primary wrongdoer) being liable. This characterisation of the liability casts doubt on its accessorial nature.

\footnotetext{
${ }^{53} \mathrm{We}$ acknowledge that the traditional language of constructive trusts may be used to support Worthington's analysis, however, that language is equally supportive of an accessorial analysis: Dietrich and Ridge, Accessories, at para. [8.1.7].
} 
Robert Stevens is a proponent of this view ${ }^{54}$ and it now appears to have been endorsed by important obiter statements from a 2017 High Court of Australia decision, IL v The Queen. ${ }^{55}$ Stevens has argued, in support of his rights theory, that there is no accessory liability in tort law, but rather that joint tortfeasor liability is explicable in terms of the attribution of one person's act to another. ${ }^{56}$ This supports Stevens' thesis that only those who infringe others' rights should be legally liable: 'The attribution of X's actions to D means that D has infringed C's rights.' ${ }^{57}$ There is no right that others not act as an accessory in tort law (unlike the position in equity, according to Stevens). . On this reasoning, the joint tortfeasor is liable as another principal, and not an accessory. ${ }^{58}$

Stevens' views find implicit support in ILv The Queen. The case concerned criminal joint enterprise liability, a form of criminal complicity liability. ${ }^{59}$ The statements by the plurality in $I L$, concerning the private law liabilities with which we are concerned here, were obiter and brief, but it is necessary to unpack their meaning in some depth. We begin with an explanation of attribution as a general tool of legal reasoning. We then discuss $I L$ : the legal context, the plurality's obiter statements, and their implications for our conception of accessory liability. We then explain our concerns with the 'attribution conception' of joint tortfeasor liability and why accessory liability is a more illuminating explanation for the relevant areas of joint tortfeasor liability. It will be necessary at several points in the following discussion to clarify what is meant by labels - such as 'primary' and 'derivative' - in the particular context.

\section{Attribution as a general tool of legal reasoning}

Attribution occurs in law whenever the conduct, mental state and/or liability of one person is treated as being that of another person. ${ }^{60}$ Attribution of conduct and/or mental state is most common in scenarios involving agency, particularly in relation to companies; indeed, for the obvious reason that a company can only operate through human agents, it is essential when determining a company's conduct or mental state. ${ }^{61}$ The rationale for attribution-based reasoning is self-evident there. Attribution of conduct and/or mental state assists in determining whether the elements of a cause of action are made out against a company (or other principal).

\footnotetext{
54 See R. Stevens, Torts and Rights (Oxford 2007).

${ }^{55}$ IL $v$ The Queen [2017] HCA 27, (2017) 262 C.L.R 268.

${ }^{56}$ See Stevens, Torts and Rights, at pp. 275-276 and 256-257.

57 Ibid at p. 262.

${ }^{58}$ Ibid., at p. 257.

${ }^{59}$ Miller v R [2016] HCA 30, (2016) 259 C.L.R. 380 (French CJ, Kiefel, Bell, Nettle and Gordon JJ).

${ }^{60}$ See generally, Bilta (UK) Ltd v Nazir (No 2) [2015] UKSC 23, [2016] A.C. 1.

${ }^{61}$ Ibid.
} 
Alternatively, the liability of one person may be attributed to another. This is one understanding of vicarious liability: an employee's liability in negligence, for example, is attributed to the employer such that the employer is liable for negligence without having personally been negligent itself. ${ }^{62}$ Attribution of liability here derives from the employment relationship and is justified by reference to policy factors relating to loss-allocation within that context.

\section{IL $v$ The Queen}

The question in $I L$ was whether the accused was guilty of the murder or manslaughter of the deceased who died as the result of an accident in the course of their criminal joint enterprise. ${ }^{63}$ The plurality (Kiefel CJ, Keane and Edelman JJ) found that as a matter of statutory interpretation the accused could not be liable for the murder of the deceased. ${ }^{64}$ Their Honours then went on, in obiter, to consider the operation of criminal joint enterprise liability. They explained that the liability involves the attribution of acts to an accused:

when two or more persons act in concert to effect a common criminal purpose, it is the acts of each person to effect their common purpose which are attributed to the others. ${ }^{65}$

This is uncontroversial so far as the criminal law is concerned, however, the same principle was said to apply in private law ('civil cases') to joint tortfeasors:

The important point is that it is the acts which are attributed from one person (the actor) to another who shares the common purpose and, by attribution, becomes personally responsible for the acts. It is not the liability of the actor which is attributed. ${ }^{66}$

\footnotetext{
${ }^{62}$ Majrowski v Guy's and St Thomas' NHS Trust [2006] UKHL 34, [2007] 1 A.C. 224, and see Paula Giliker, Vicarious Liability in Tort: A Comparative Perspective (Cambridge University Press, 2010) p 15, concluding that attribution of liability is the dominant view in the UK; but contra. Stevens, Torts and Rights, at pp. $257 \mathrm{ff}$ who concedes that the attribution of liability is the current judicial position, but argues for the attribution of acts model. See also, R Stevens, "Vicarious Liability or Vicarious Action?" (2007) 123 L.Q.R. 30. The UK Supreme Court's recent efforts at fundamentally reframing vicarious liability to produce 'a modern theory of vicarious liability' (in the words of Lord Reed in Cox v Ministry of Justice [2016] UKSC 10, [2016] A.C. 660 at [24] describing the Supreme Court's decision in The Catholic Child Welfare Society v Various Claimants and the Institute of the Brothers of the Christian Schools [2012] UKSC 56, [2013] 2 A.C. 1) have focused on where the boundaries of liability should be drawn. They have not revisited the older debate as to the competing merits of theories of vicarious liability that concern the attribution of liability versus attribution of acts. See also, e.g., Paula Giliker, 'Analysing Institutional Liability for Sexual Abuse in England and Wales and Australia: Vicarious Liability, NonDelegable Duties and Statutory Intervention' (2018) 77(3) Cambridge Law Journal 506-538. In Australia see, e.g., Kable v State of New South Wales (2012) 268 F.L.R. 1, 18-19 at [52]-[53]. However, recently the question was said to still be open in Australia: Pioneer Mortgage Services Pty Ltd v Columbus Capital Pty Ltd [2016] FCAFC 78 at [48]-[58] (Davies, Gleeson and Edelman JJ).

${ }^{63}$ See Crimes Act 1900 (NSW) s. 18.

${ }^{64}$ IL $v$ The Queen [2017] HCA 27, (2017) 262 C.L.R. 268 at [25].

${ }^{65}$ Ibid., at para. [2]. See also para. [26]. See also Andrew Dyer, 'The "Australian Position” Concerning Criminal Complicity: Principle, Policy or Politics’ (2018) 40 Sydney Law Review 289, 294.

${ }^{66}$ Ibid., at para. [29].
} 
Their Honours went on to locate their statements regarding attribution within the context of a distinction, often drawn in the criminal law, between 'primary liability' and 'derivative liability': ${ }^{67}$

Liability which is primary can involve attribution of the acts of another. But the liability remains personal to the accused. Liability which is derivative depends upon attribution to the accused of the liability of another. If the other is not liable then the accused cannot be made liable. ${ }^{68}$

Two observations are pertinent before going further. First, the nature and precise operation of criminal joint enterprise liability are contested and differ across jurisdictions; its relationship to other complicity doctrines such as criminal aiding and abetting liability is unclear. ${ }^{69}$ With respect, it seems odd to use an obiter discussion of this liability as a springboard for generic statements about the conceptual foundations of civil law. The second observation relates to terminology. The potential for confusion is considerable here because 'primary' and 'derivative' have various meanings in accessory liability discourse as well as a very specific meaning in criminal complicity discourse. 'Primary' is used by the plurality in $I L$ to describe joint tortfeasor liability (said to be based on the attribution of acts) as being personal to a defendant. And 'derivative' is used to describe liability which has been attributed to the defendant. It is correct that a joint tortfeasor is always liable as principal for the same primary wrong as committed by the other tortfeasor. But this type of liability (for the same wrong as another) is often also described in the context of private law as 'derivative' (or 'secondary'), since it is for the same, and not a different, wrong as committed by PW. ${ }^{70}$ That is, the same term ('derivative') has completely opposite meanings in the same context (and can also mean the same as 'primary'), depending upon whether one is speaking from a criminal law perspective or from a particular conceptual perspective within private law. Thus, what appears

\footnotetext{
${ }^{67}$ Ibid., at para. [30] (citing Osland $v$ The Queen (1998) 197 C.L.R. 316, 341-342 at [71]).

${ }^{68}$ Ibid., at para. [34] citing Pioneer Mortgage Services Pty Ltd v Columbus Capital Pty Ltd [2016] FCAFC 78 at [48]-[56]. See also Gageler J at para. [103] (agreeing that acts are attributed for purposes of joint criminal liability) but at para. [107], leaving open whether extended joint criminal enterprise liability is primary or derivative. Contrast Bell and Nettle JJ at para. [65], who conclude that it is only the acts of the other party that comprise the actus reus of an offence, that are to be attributed.

${ }^{69}$ As to whether (1) joint criminal enterprise is a form of accessory liability and (2) the level of fault that is required to establish is the same as it is for aiding and abetting accessory liability, see Jogee $v R$ [2016] UKSC 8, [2016] 2 All E.R. 1; $R v$ Ruddock [2016] UKPC 7, [2016] 2 W.L.R. 681 (on joint appeal, answering yes to both questions); contrast Miller $v$ The Queen (2016) 259 C.L.R. 380 and Hksar v Chan Kam Shing [2016] HKCFA 87, all answering no to both questions. See further A. Simester, 'Accessory Liability and Common Unlawful Purpose' (2017) 133 L.Q.R. 73.

${ }^{70}$ See, e.g., S. Elliott and C. Mitchell, "Remedies for Dishonest Assistance" (2004) 67 Modern Law Review 16; P. Sales, "The Tort of Conspiracy and Civil Secondary Liability" (1990) 49 C.L.J. 491, 502ff.
} 
to be a very simple and straightforward statement by the plurality is easily capable of being misconstrued.

\section{Implications of attribution-based reasoning for an accessorial conception of the law}

What are the implications of Stevens' attribution thesis, seemingly endorsed in the High Court, for our accessorial conception of the liability of joint tortfeasors who procure or act in concert to commit a tort? Although it is not spelt out in the plurality's statement, a logical consequence of the argument that the attribution of one person (X)'s acts to another (Y) makes the latter personally and primarily liable (subject to other elements of the offence/wrong being satisfied), is that Y's liability is not amenable to an accessorial analysis. This is because Y personally satisfies the elements of the wrong, through attribution of X's acts regardless of whether X, having committed the requisite acts, has also personally satisfied all the elements of the wrong (that is, X may not have committed a wrong at all). ${ }^{71}$ The attribution of acts thesis drives a characterisation of the liability as non-accessorial; this is clearly spelt out in Stevens' work, even if not made explicit by the High Court. Hence, the challenge to any conception of accessory liability in its application to joint tortfeasors ${ }^{72}$ is twofold. First, does the attribution of acts explanation for that liability render our accessorial explanation redundant? Secondly, as there can be no accessory liability without there being a primary wrong, does the reasoning in $I L$ suggest that the liability of joint tortfeasors cannot be conceptualised as accessorial in any event, ${ }^{73}$ because sometimes the party whose acts are attributed may not have committed any wrong?

\section{The shortcomings of attribution reasoning}

Attribution reasoning is undoubtedly an important tool in the law. For example, attribution in relation to agents and principals is clearly justified, based on their pre-existing relationship; the existence of a pre-existing employment relationship (or perhaps, one akin to employment) also explains vicarious liability, though whether that is based on the attribution of employees' acts, or of employees' liability, is contested. However, the use of attribution reasoning in relation to all cases of joint tortfeasors, including where accessorial conduct is at issue, glosses over the reason for attribution in the distinct and separate contexts. The reasons for attributing acts (accepting that analysis for present purposes) of an employee or agent to the employer or

\footnotetext{
${ }^{71}$ Stevens, Torts and Rights, at p. 257.

${ }^{72}$ Evaluation of the plurality's statements in $I L$ as they apply to forms of criminal accessory liability is beyond the scope of this article.

${ }^{73}$ Cf., Stevens, Torts and Rights, at p. 256.
} 
principal, do not necessarily translate to the attribution of acts of the procured to the procurer, or the party to a common design who commits the tort, to the one who does not. Any theory of attribution needs to explain the reasons for attribution in those very different circumstances. If one goes behind the language of attribution and unpacks the justifications for its application to joint tortfeasors, it becomes apparent that where Y has not personally committed the relevant acts constituting the wrong, the only reason for attribution is because of Y's involvement in $X$ 's wrongful scheme (whether procuring it, perhaps as an assistant to it, ${ }^{74}$ or conspiring with $\mathrm{X}$ to commit the scheme and taking steps to carry it out). Of necessity, one must show wrongful conduct by $\mathrm{X}$ (regardless of whether $\mathrm{X}$ may not be liable in the event, to which matter we turn to in the next section). In other words, it is an accessorial analysis in this factual context that tells us why we might attribute one person's acts to another. The argument that the attribution of one person's acts (X) to another (Y) makes the latter personally and primarily liable, and therefore not an accessory, conceals what is, in substance, an accessorial analysis.

It might be argued that in some factual scenarios it will be very difficult to distinguish who is an accessory and who is a primary wrongdoer, whereas an attribution of acts conception of liability avoids such niceties by attributing each parties' acts to the other. ${ }^{75}$ For example, where two parties both commit the same act together at the same time (say, by both pushing someone) or agree to commit different parts of a chain of actions (say, by agreeing that one pushes someone and the other trips them), thereby committing a tort or torts, it is not obvious whether an accessorial or primary liability arises. It is true that it is difficult to distinguish, at times, accessory liability from true primary liability, although this is not an issue confined to accessory liability: it is often the case that a factual scenario gives rise to more than one, sometimes overlapping, liability. We may well say each party has committed the one primary wrong, including for pragmatic reasons, where it is difficult to disentangle the conduct. ${ }^{76}$ Alternatively, in criminal law, English common law draws the distinction between primary liability and accessory liability by asking whether a party, D, has contributed by his or her own acts, 'as distinct from anything done by [the principal offender] with D's assistance ..., to the

\footnotetext{
${ }^{74}$ Whether mere assistance alone suffices in tort law as a conduct element for accessory liability in tort law is still an open question, though the UKSC's decision in Sea Shepherd UK v Fish \& Fish Ltd [2015] UKSC 10, [2015] A.C. 1229 would seem to suggest that assistance only suffices if a further element of a common design is made out, but does not spell out what further conduct (or mental state) is needed to establish such design.

${ }^{75} \mathrm{We}$ are indebted to one of the anonymous reviewers for this point.

${ }^{76}$ One can then go on to argue that if the agreement, or joint or mutual intention of the parties, is the underlying rationale for such attribution, then such attribution also applies to $\mathrm{Y}$ even where $\mathrm{X}$ alone has performed all the conduct elements of an offence or wrong, so long as $\mathrm{X}$ acted as part of the agreed plan with $\mathrm{Y}$.
} 
actus reus' ${ }^{77}$ If $\mathrm{D}$ did so, then he or she is a principal offender; if not, then $\mathrm{D}$ can only be an accessory. That test may not be perfect, but nonetheless it is a reasonable starting point.

Every theory faces these difficult exercises in line-drawing. For example, the plurality in $I L v$ The Queen drew a distinction between the attribution of acts (referring to complicity) and the attribution of liabilities (referring to aiding and abetting). ${ }^{78}$ But where does one draw the line between complicity and aiding and abetting, given that the former can be implied from acts of assistance, and that factually, there exists a spectrum of possible acts of involvement of one party in another's wrongdoing including: procuring another; conspiring with another in clear, express plans; impliedly conspiring; being an active and dominant assistant; to being a reluctant minor player in another's wrongful activity? ${ }^{79}$

In our view, neither the attribution of acts (or, for that matter, of liability) adequately explains why an accessory is liable; indeed, only accessorial reasoning explains why attribution (if it is needed) occurs when it does. An accessory is liable for her own culpable conduct in involving herself, with a requisite mental element, in PW's wrongful conduct. Notions of attribution are not needed in that context and in private law, accessorial liabilities are not generally described in those terms.

\section{Must PW be liable for the wrongful conduct?}

Still problematic for the utility of our conception of accessory liability, however, is the second question raised by the plurality's statements in $I L$ : how can parties be accessories to others' 'wrongs' if those others are not themselves liable for those wrongs — in short, are not wrongdoers? ${ }^{80}$ The question is pertinent to all accessory liabilities regardless of the form of liability (whether for the same or a different wrong to that of PW).

The plurality's distinction in $I L$ between 'primary' liability (including where PW's acts are attributed to A) and 'derivative' (attributed) liability was made in the context of joint criminal

\footnotetext{
77 See David Ormerod, Smith and Hogan's Criminal Law, 13 $3^{\text {th }}$ ed (Oxford University Press, 2011) at p. 190. Compare $R v$ Gnango [2011] UKSC 59; [2012] 1 A.C. 827 at [129] (Lord Kerr) and see $R v$ Kennedy (No. 2) [2007] UKHL 38; [2008] Crim L.R. 223. This is also the position under Australian Criminal Code states (see, eg, $R v$ Sherrington and Kuchler [2001] QCA 105), but is contrary to the position at Australian common law: see, e.g., Osland v The Queen (1998) 197 C.L.R 316.

78 [2017] HCA 27, (2017) 262 C.L.R. 268 at [2], [26], [29].

79 As Simester, 'Accessory Liability and Common Unlawful Purpose', 77, states, it is 'entirely sensible' that a conspirator in a joint criminal enterprise (JCE) is viewed as an accomplice (or aider and abettor) for the crime agreed to. The conspiracy is itself a form of participation. He takes this view while defending a distinct approach to extended JCE liability where a further and different crime is committed.

${ }^{80}$ This is a different question to whether a claim needs to have been brought against PW, the answer to which is unproblematic: no.
} 
enterprise liability, which their Honours considered to be a form of primary liability; they were contrasting criminal aiding and abetting (accessory) liability which they considered to be derivative. The plurality concluded that in the latter type of liability, an 'accessory' is only liable if the principal offender is liable. However, although this is seemingly the accepted position in criminal law, even here, the conclusion is contestable, and courts have struggled to avoid the consequences of applying such a principle in a range of factual circumstances. ${ }^{81}$ It is clear that if a party involves herself in an offence committed by an offender who, say, successfully pleads a defence of insanity or automatism, such party will be found liable. ${ }^{82}$ There are different explanations that might be given for such liability. Their Honours in $I L$ sought to explain such decisions as either being cases of joint criminal enterprises ${ }^{83}$ or as cases of 'innocent agency'; ${ }^{84}$ but those explanations may in some cases be strained on the facts or in logic, ${ }^{85}$ and some courts have found that aiding and abetting liability can and should arise even where PW is not liable. ${ }^{86}$

Irrespective of the position at criminal law, however, we would argue that in private law an accessory can be liable even if PW is not because, for example, PW can establish an excuse. Although this seems illogical — how can A be involved in PW's 'wrong' if PW has not committed a 'wrong'? - PW must still have engaged in the wrongful conduct. In other words, A can be liable for involvement in PW's putative wrong, even if PW herself is excused by

\footnotetext{
${ }^{81}$ Certainly, the opposite appears to be the position in English law. See, e.g., Bourne $v R$ (1952) 36 Cr.App.R 125; $R v$ Austin [1981] 1 All E.R. 374; $R v$ Cogan [1976] Q.B. 217. The 'no liability for one, no liability for the other' rule is also undermined by the fact that for aiding and abetting liability, in Australian common law, an accused can be found liable for a more serious offence than the principal offender. See, e.g., Likiardopoulos $v$ R (2012) 247 C.L.R. 265.

${ }^{82}$ Similarly, where a young child lacking capacity commits an 'offence': see Schultz v Pettitt (1980) 25 S.A.S.R. 427. Some statutory schemes are explicit on the point: eg, Criminal Code 1995 (Cth) s. 11.2(5).

83 This may require a reinterpretation of cases contrary to the reasons actually given: see the explanation of the English cases cited at $\mathrm{n} 77$ above by McHugh J in Osland $v$ R (1998) 197 C.L.R. 316 and IL v The Queen [2017] HCA 27, (2017) 262 C.L.R. 268 at [34]-[40] (Kiefel CJ, Keane and Edelman JJ) as being based on joint criminal enterprise, rather than aiding and abetting (accessory) liability. Compare Bell and Nettle JJ in $I L$ at para. [83][88].

${ }^{84}$ The term 'innocent agency' is of uncertain meaning and the limitations that apply to that principle are not clear and therefore that concept is not necessarily helpful as an explanatory concept. Further, the term can be used to refer to two, sometimes not easily distinguishable, situations. These are (1) where the defendant is an accessory to an (excused) wrongful act, eg, probably where an insane person decides to kill $\mathrm{X}$ and $\mathrm{A}$ aids him by providing him with poison: G. Williams, "Theory of Excuses" (1982) Criminal Law Review 732, particularly at pp. 735738 (the accused is not an accountable agent but the underlying wrongfulness of the conduct is not removed); or (2) where the defendant is the only principal offender against whom all elements of the offence can be made out, albeit perhaps through indirect conduct (e.g., defendant gives $\mathrm{X}$ food to feed victim that unbeknownst to $\mathrm{X}$ is poisoned: c.f. $R v$ Michael (1840) 9 C\&P 356, 173 E.R. 867). Compare the discussion of innocent agency in $I L v$ The Queen [2017] HCA 27, (2017) 262 C.L.R 268 at [81]-[88] (Bell and Nettle JJ).

${ }^{85}$ See Williams, 'Theory of Excuses', at p. 737.

${ }^{86}$ See cases cited in $n 77$ above, and note also Gibbs J in Matusevich v R (1977) 137 C.L.R. 633, 636. Compare Gibbs J in White v Ridley (1978) 140 C.L.R. 342, 346-347.
} 
some defence or reason personal to herself. ${ }^{87}$ That position seems to apply in cases of accessory liability that is independent, in equity and common law, ${ }^{88}$ but also probably applies even where the accessory is liable for the same wrong as the primary wrongdoer in tort. ${ }^{89}$ Of course, if a defence takes away the inherent wrongfulness of PW's conduct altogether such that no wrong at all has been committed (such as self-defence, or consent), then accessory liability rightly cannot arise.

\section{UNIFORMITY AND SIMPLIFICATION: ALTERNATIVE CONCEPTIONS OF ACCESSORY LIABILITY ITSELF}

\section{A. Introduction}

A different challenge to the utility of the concept of accessory liability in private law comes from commentators who seek to simplify the law by elevating accessory liability to a uniform cause of action. Attempts at simplification tend to prioritise clarity and logic in the expression of the law over fidelity to the reasoning of the courts and to the 'disorderliness' ${ }^{90}$ that is a byproduct of our legal system. In this Part we argue that conceptions of accessory liability that prioritise uniformity and simplicity risk distorting the law and may lead to unjust outcomes. We begin by describing the uniformity approach and, specifically, key elements of the conceptual framework proposed by Paul Davies. ${ }^{91}$ We then explain three concerns with Davies' approach. The first is a general concern relating to its lack of 'fit' with statutory accessory liability schemes. The second and third concerns relate to claims that are central to Davies' analysis: first, that the conduct and mental elements of an accessory liability claim must be considered in isolation from each other; and secondly (and relatedly), that there should be a uniform requirement of subjective actual knowledge.

\section{B. A Uniform Conception of Accessory Liability in Private Law}

\section{Introduction}

\footnotetext{
${ }^{87}$ See Dietrich and Ridge, Accessories, at para. [3.6].

${ }^{88}$ E.g., for inducing breach of contract, the breaching party need not be liable, either because the contract is unenforceable or because the breaching party has excluded the liability to pay damages for breach. See Dietrich and Ridge, Accessories, at para. [6.3.2]. Similarly, in equity a trustee's liability for breach of trust might be excused, whereas the procurer of the breach would remain liable. See also Michael Wilson \& Partners Ltd $v$ Nicholls (2011) 244 C.L.R. 427.

${ }^{89}$ See the operation of defences based on the absence of malice in defamation law, which only apply as against those joint tortfeasors who are activated by malice but not against the others: see Cornwall v Rowan [2004] SASC 384 at [452] and Egger $v$ The Viscount Chelmsford (1965) 1 Q.B. 248, 265.

${ }^{90}$ Fistar v Riverwood Legion and Community Club Limited (2016) 91 N.S.W.L.R. 732, 743-744 at [48]-[53] (Leeming JA).

${ }^{91}$ P.S. Davies, Accessory Liability (Oxford 2015).
} 
Peter Birks once called for 'one law on the civil liability of accessories' ${ }^{92}$ That call was heeded by Davies in his book Accessory Liability, ${ }^{93}$ developing upon an attempt by Philip Sales to identify uniform accessory rules. ${ }^{94}$ Davies describes the framework of accessory liability in broadly similar terms to us, namely, (1) that a primary wrong is established and (2) that the accessory 'did something in relation to the primary wrong (the conduct element) and (3) was at fault in some way (the mental element)'. ${ }^{95}$ However, unlike our conception of the framework as being dynamic in operation and fluid in content, Davies calls for it to be applied in a fixed and uniform manner. Davies' view is that the framework operates as a generic cause of action, rather than as an organising principle:

A general principle of knowing assistance or inducement should apply regardless of the nature of the primary right of the claimant that has been infringed. ${ }^{96}$

Accordingly, Davies insists upon a fixed mental element: subjective actual knowledge (including wilful blindness ${ }^{97}$ ) by A of PW's commission of the wrong is essential. ${ }^{98}$ Davies concludes thus:

The law should be easy to state, even if, at times, difficult to prove: only a defendant who knowingly assists a primary wrong risks accessory liability. ${ }^{99}$

He concedes that this requires substantial changes to the law. ${ }^{100}$

\section{Accommodating statutory accessory liabilities}

One difficulty with Davies' approach is that his book concerns the doctrines of equity, contract and tort, which means that he engages with statute only peripherally. ${ }^{101}$ The ubiquity of statute

\footnotetext{
${ }^{92}$ P. Birks, "Civil Wrongs: A New World" in F.M.B. Reynolds and P. Birks (eds.) Butterworth Lectures 1990-91 (London 1992) 100.

${ }^{93}$ Davies, Accessory Liability. Davies' book was published too late for us evaluate it in Dietrich and Ridge, Accessories.

${ }^{94}$ Sales, "The Tort of Conspiracy and Civil Secondary Liability".

${ }^{95}$ Davies, Accessory Liability, at p. 1.

${ }^{96}$ Ibid., at p. 283.

${ }^{97}$ Ibid., at p. 283: '[C]onsciously turning a blind eye to known facts'.

${ }^{98}$ Ibid., at pp. $44-47,53$, ch. 9.

${ }^{99}$ Ibid., at p. 285.

${ }^{100}$ Ibid., at p. 283.

${ }^{101}$ Recently, Sir Richard Arnold and Davies have called for legislation to be amended to delete specific provisions that impose accessory liability on the basis of different (statutory) principles rather than on general tortious accessory principles. Sir R. Arnold and P. Davies, "Accessory Liability for Intellectual Property Infringement: The Case of Authorisation" (2017) 133 L.Q.R. 442, particularly at 443-444, 466-468 (arguing for the removal of statutory liability for 'authorising' a breach of copyright so as to provide for uniform accessory rules). Their assumption is that the outcomes of the application of the two distinct tests would be the same. That may be an arguable proposition in English law, but is improbable in Australian law. See, eg, Career Step, LLC v TalentMed Pty Ltd (No 2) [2018] FCA 132 (Robertson J).
} 
in modern private law and, specifically, the many instances of statutory liability that conform to an accessorial conceptual framework, presents a challenge for a uniformity-driven conception of accessory liability that focuses only on judge-made doctrines developed at common law or in equity ${ }^{102}$ However, that very ubiquity demands that statute be accommodated.

Our conception of accessory liability can and does accommodate statute because the content and relationship of the elements of liability are not fixed. This, we suggest, is of more value to legislators and law reformers than a prescriptive conception that prioritises uniformity, regardless of context. ${ }^{103}$ The dynamic operation of our framework encompasses all manifestations of accessory liability across private law and can provide a wealth of data on how such questions might be answered in a holistic manner with due regard for the particular policy and legal context. Furthermore, such an approach may also yield insights as to the resolution of intractable problems in judge-made law; the insights to be gained are not all oneway. ${ }^{104}$

\section{The dynamic relationship of the elements of accessory liability}

As explained in Part II, there is a dynamic interplay between the conduct and mental elements of the preferred conception for accessory liability. A's culpability reflects A's conduct and mental state in combination and having regard to the primary wrong committed. As a general rule, the more active $\mathrm{A}$ is in bringing about the primary wrong, the less A may need to know about PW's planned wrongdoing in order to be liable; the less active $\mathrm{A}$ is, then the more detailed information A will probably need to know and to a higher degree in order to be liable. Where both elements are weak, the case for liability is also weak. Also relevant are the egregiousness of the primary wrong and the purposes and values that underpin that primary

\footnotetext{
102 See M. Leeming, "Theories and Principles Underlying the Development of the Common Law - The Statutory Elephant in the Room" (2013) 36 UNSW Law Journal 1002; R. Grantham and D. Jensen, "Coherence in the Age of Statutes" (2016) 42 Monash University law Review 360.

${ }^{103}$ Cf., D. Foxton, “Accessory Liability and Section 213 Insolvency Act 1986” [2018] Journal of Business Law 324.

104 A. Burrows, "The Relationship Between Common Law and Statute in the Law of Obligations" (2012) 128 L.Q.R. 232. For specific examples, see J. Dietrich, "The Liability of Accessories under Statute, in Equity, and in Criminal Law: Some Common Problems and (Perhaps) Common Solutions" (2010) 34 Melbourne University Law Review 106; E. Bant, "Statute and Common Law: Interaction and Influence in Light of the Principle of Coherence" (2015) 38 UNSW Law Journal 367, 382-385.
} 
wrong. Most of the work in this respect tends to be done by doctrinal or statutory formulation, although it may be placed upon the individual decision-maker. ${ }^{105}$

Conversely, the elements of Davies' conception of accessory liability have fixed content. The conduct element, for example, is either satisfied or not. If a third party's involvement does not satisfy the minimal assistance required, no further inquiry is needed. Similarly, Davies insists that subjective actual knowledge is essential. Thus, he rejects the argument that a lesser degree of knowledge may suffice where, for example, A seeks to procure a wrong (or an outcome that turns out to be a wrong). ${ }^{106} \mathrm{He}$ does so on the grounds of simplicity and uniformity: ${ }^{107}$

This approach would render the law very complex and require fine distinctions to be made about the type of conduct element involved. ... There is no need for the law to introduce the complexities inherent in varying the mental element according to the precise mode of participation in the primary wrong. ${ }^{108}$

Similarly, after stating that ' $[\mathrm{t}]$ he law is clearly much easier to state if the mental element does not vary according to the nature of the defendant's participation', Davies describes the problem as follows:

[a single mental element] happily avoids the complexities inherent in the tremendously difficult exercise of managing fine distinctions between different conduct elements and mental elements. ${ }^{109}$

But this is to misunderstand the dynamic operation of accessory liability, namely that it does not draw fine distinctions at all. Establishing fault involves an overall assessment of the conduct and mental state of a person in the context of the circumstances in which it occurs. This means of course, that as the courts repeatedly stress, liability requires a close analysis of the facts. ${ }^{110}$

\footnotetext{
${ }^{105}$ See the examples given in the text to nn 5-9 above. The influential judgment of Finn, Stone and Perram JJ in the Federal Court of Australia in Grimaldi v Chameleon Mining NL (No 2) (2012) 200 F.C.R. 296 at [247], albeit encompassing equitable participatory liability more generally, captures the dynamic operation of the law: $[\mathrm{P}]$ articipatory liability as it evolved in equity ... was not based on inflexible formulae. Given the variety of circumstances in which, and bases on which, a third party could be characterised as a wrongdoer in equity...varying importance has been given to three matters: (i) the nature of the actual fiduciary or trustee wrongdoing in which the third party was a participant; (ii) the nature of the third party's role and participation, eg as alter ago, inducer or procurer, dealer at arm's length, etc; and (iii) the extent of the participant's knowledge or, assumption of the risk of, or indifference to, actual, apprehended or suspected wrongdoing by the fiduciary.

106 See Davies, Accessory Liability, at pp. 127-129, referring to P.D. Finn, "The Liability of Third Parties for Knowing Receipt or Assistance" in D.W.M. Waters (ed.), Equity, Fiduciaries and Trusts (Carswell, 1993) 215217. P. Ridge, "Participatory Liability for Breach of Trust or Fiduciary Duty" in J. Glister and P. Ridge (eds.), Fault Lines in Equity (Oxford 2012) 139.

${ }^{107}$ Davies, Accessory Liability, at pp. 127-129, 282.

108 Ibid., at pp. 128-129.

${ }^{109}$ Ibid., at p. 282.

${ }^{110}$ Sea Shepherd UKv Fish \& Fish Ltd [2015] UKSC 10, [2015] A.C. 1229 at [56].
} 


\section{The mental element of accessory liability}

Davies either rejects cases that extend liability beyond actual knowledge as over-extending accessory liability, ${ }^{111}$ as wrong, ${ }^{112}$ or as not accessory liability at all. ${ }^{113}$ The difficulty with this approach is that a uniform requirement of subjective actual knowledge is easily evaded and does not reflect the current law. As will be discussed below, contrary to the uniform conception, there are differences across private law as to the degree and content of A's knowledge that are required to satisfy the mental element of accessory liability. Nor will a lesser requisite degree of knowledge necessarily implicate non-culpable defendants. For example, where A's effort is directed at procuring an outcome, it may not matter much whether A actually knows precisely how PW achieves that outcome, if there was a high degree of risk that PW can only achieve A's objectives through wrongdoing. If A exerts pressure on a trustee, $\mathrm{PW}$, to withdraw trust funds and invest them in A's business where A has some reason to believe that this may be an unauthorised investment and breach of trust, why should A be able to respond: 'But I did not know; I never saw the trust instrument'? ${ }^{114}$ And it must surely be relevant, when assessing A's fault, that A has profited from PW's conduct in having more capital investors. ${ }^{115}$ Not surprisingly, the rules of equity reflect that standard, where recklessness as to a breach occurring is accepted as sufficing for liability, that is, where there is a 'substantial and unjustifiable risk' of a breach. ${ }^{116}$

Another weakness in insisting upon actual knowledge in all circumstances is that this is of limited use unless one articulates precisely what it is that A must know: the content of A's knowledge. The difficult work of adjudicating A's culpability is largely done by determining the requisite content of knowledge that A must have had about that wrongdoing. The cases are

\footnotetext{
${ }^{111}$ See, e.g., Davies, Accessory Liability, at pp. 114-16.

112 See, e.g., ibid., at pp. 203-205.

${ }^{113}$ See, e.g., ibid., at pp. 66-68.

114 In some scenarios wilful blindness may be apparent, but not all scenarios could be made to fit that characterisation. Compare, in the context of inducing breach of contract, the fact that it is not for A to claim that for all she knew, there may have been a lawful way for PW to terminate the contract. See, eg, Delphic Wholesalers Pty Ltd v Elco Food Co Pty Ltd (1987) 8 I.P.R. 545, 553-554.

115 Davies, Accessory Liability, at pp. 129-30, criticises the view of one of us, Ridge, "Participatory Liability for Breach of Trust or Fiduciary Duty", at pp. 131-141, that benefit to A is a relevant consideration in assessing A's culpability. We adhere to that view: Dietrich and Ridge, Accessories, at para. [8.3.2.3]. Such benefit strengthens the likelihood of liability for reckless conduct.

116 See, e.g., Imobilari Pty Ltd v Opes Prime Stockbroking Ltd [2008] FCA 1920 at [28] (Finkelstein J).

The same position appears to apply in the tort of inducing breach of contract, where A may be liable where there is a substantial risk that PW will breach her contract. An inducer of a breach of contract can rarely know the precise terms of PW's contract and PW's options, lawful or otherwise, as to how to respond to A's inducing conduct. Requiring near certainty of breach (that is, actual knowledge that PW will breach), rather than merely a high degree of risk of such a breach, would make A's liability almost impossible to establish.
} 
often focussed on entirely factual questions of what A knew about the circumstances of PW's conduct and intentions, and what A needed to know, in order to have sufficient cognition of the potential commission of a wrong when A offered assistance to PW, or induced PW, to carry out certain acts. These include matters such as the time of the wrong, the place of the wrong, the intended victim(s), whether indeed PW's conduct is a wrong (and with what generality or specificity A identified the intended wrong). The issue is often encapsulated in terms of the 'essential matters' of PW's wrong. ${ }^{117}$ If the law insists on actual knowledge at all times, this may be circumvented quite simply by stating in broad, rather than precise, terms what it is that A must know. In other words, a rigid requirement of 'actual knowledge' might lead courts to find that $\mathrm{A}$ indeed had actual knowledge, but of much less detailed information about PW's intended conduct and the surrounding circumstances than might otherwise have been required if the law demanded a less onerous degree of knowledge.

Thus, fine distinctions between degrees of knowledge are by the way without clear identification of the requisite content of A's knowledge on the facts of a given case. Similarly, there may not be a single answer to the question of the degree to which A knew particular facts. A may subjectively ('actually') know some key facts, but have been merely reckless in relation to others, going to PW's intentions and plans (or, say, PW's relationship with the claimant and the details of PW's obligations). Thus, any supposed certainty in the application of a fixed requirement of actual knowledge is, we suggest, illusory.

In any case, what is clear is that there is a diversity of accessory principles throughout private law and these do not necessarily conform to a uniform requirement of subjective actual knowledge of PW's wrongdoing. One example, namely the position in equity, suffices, but any number of others could be given. ${ }^{118}$ In equity, some jurisdictions have accepted that a lesser

\footnotetext{
${ }^{117}$ See Dietrich and Ridge, Accessories, at para. [3.4.2.2].

${ }^{118}$ For example, in the tort of inducing breach of contract, it suffices that A was recklessly indifferent to the possibility that PW's conduct amounts to a breach; that is, it need not be a near certainty that a breach will occur. Similarly, the law is particularly complex concerning the liability of directors and officers for company wrongdoing, especially where they have procured the company to engage in conduct that turns out to be wrongful. Although most cases are consistent with the need for some knowledge, this need not necessarily be actual knowledge. See, eg, seemingly accepting a recklessness standard, that an infringement was substantially likely to follow, see Societa Esplosivi Industriali SpA v Ordnance Technologies (UK) Ltd (No 2) [2007] EWHC 2875 (Ch), [2008] 2 All E.R. 622, particularly at pp. 649-50 para. [95] (Lindsay J), and the state of knowledge of the director in that case. In limited circumstances directors may be liable (albeit, unusually so) even in the absence of knowledge of the wrongfulness of the company's conduct: that is, liability may be tantamount to strict. Particularly in the context of intellectual property infringements, the predominant view appears to be that A (a director or officer) need not necessarily know that PW Co's conduct is wrongful, that is tortious or infringing. See, e.g., Microsoft Corporation v Auschina Polaris Pty Ltd (1996) 71 F.C.R. 231, 235 (Lindgren J). That proposition seems uncontroversial. See also C Evans \& Sons Ltd v Spritebrand Ltd [1985] 2 All E.R. 415, 424- 425 (Slade LJ),
} 
mental state than subjective actual knowledge may suffice for accessory liability. In Australia knowledge by A of circumstances that 'would indicate the facts to an honest and reasonable man' is the minimum level of required knowledge. ${ }^{119}$ That extension beyond actual knowledge is aimed at capturing the morally 'obtuse', who do not recognise an impropriety. ${ }^{120}$ Similarly, the English approach reflects a pragmatic acknowledgement that it is unwise to pin down the degree or content of A's knowledge required for liability in equity:

The individual is expected to attain the standard which would be observed by an honest person placed in those circumstances. It is impossible to be more specific. ${ }^{121}$

In summary, a uniform conception of accessory liability places pressure on the legal rules and can lead to strained or artificial interpretations of a complex legal regime. This creates its own uncertainty. The uniformity approach assumes the virtue of simplicity and logic in the expression of the law, but why must the law have an internal logic at all costs? A conception of accessory liability that is too pristine runs the risk of misrepresenting current law and distorting its future development.

V. CONCLUSION The premise of the various conceptions of private law considered in this article is that it is possible through scholarly work to influence and improve the law's development. However, there is an inevitable tension between the search for clarity and illumination of fundamental principles (which may lead the theorist away from current expressions of the law) and the potential for the theory to make a useful contribution to development of the law. An additional challenge for any theory involving accessory liability is ambiguous terminology, particularly terminology that was either not present in the traditional doctrinal discourse or is used in different senses in different parts of the law. Of course, the beauty of the common law is its ability to smooth out, in incremental fashion, the blunt instrument of legal theory: adopting its best features and rejecting the rest. Nonetheless, the process may be painful and is not of much comfort to litigants along the way. Recently, some commentators and judges have sought to dismiss the relevance to private law of the label and/or concept of accessory liability. Others have sought to elevate the accessory conception to a

followed, e.g., in Handi-Craft Company v B Free World Ltd [2007] EWHC B10 (Pat), but also rejected, e.g., in Root Quality Pty Ltd v Root Control Technologies Pty Ltd (2000) 177 A.L.R. 231 at [136].

119 See Farah Constructions Pty Ltd v Say-Dee Pty Ltd (2007) 230 C.L.R. 89 at [177], and Consul Development Pty Ltd v DPC Estates Pty Ltd (1975) 132 C.L.R. 373. It is level (iv) knowledge under the Baden scale: Baden v Société Générale pour Favoriser le Développement du Commerce et de l'Industrie en France SA [1993] 1 W.L.R. 509.

${ }^{120}$ Farah Constructions Pty Ltd v Say-Dee Pty Ltd (2007) 230 C.L.R. 89 at [177]; Grimaldi v Chameleon Mining NL (No 2) (2012) F.C.R. 296 at [267].

${ }^{121}$ Royal Brunei Airlines Sdn Bhdv Tan [1995] 2 A.C. 378, 390. 
single and simplified cause of action that applies uniformly throughout private law. Our conception of accessory liability pursues a path between these extremes. Accessory liability is important and operates throughout private law but does not do so uniformly. A conception of accessory liability, the specific content of which must be fleshed out by reference to the values and purposes underlying the law of the primary wrong, in our view, most accurately and straightforwardly describes a fundamental legal norm operating across private law and is a useful vehicle for developing the law where that is necessary. 